\title{
PENGUATAN PERAN KELUARGA DALAM PENCAPAIAN TARGET REGULASI GULA DARAH PASIEN DIABETES MELITUS DI RS SANJIWANI
}

\author{
W Eka Saputra ${ }^{1,2}$, DM Sadguna ${ }^{1,2}$, DAP Niti Widari ${ }^{3}$ \\ ${ }^{1}$ Departemen Ilmu Penyakit Dalam RS Sanjiwani Gianyar \\ ${ }^{2}$ Fakultas Kedokteran dan Ilmu Kesehatan, Universitas Warmadewa \\ ${ }^{3}$ Fakultas Ekonomi Universitas Warmadewa
}

\begin{abstract}
Abstrak
Diabetes Melitus (DM) merupakan kelompok penyakit metabolik yang ditandai dengan tingginya kadar glukosa di dalam darah (hiperglikemia) yang diakibatkan gangguan sekresi insulin, penurunan kerja insulin atau akibat dari keduanya. Target regulasi kadar gula darah pada pasien diabetes adalah kunci keberhasilan menenkan kesakitan serat mencegah munculnya komplikasi DM seperti gagal ginjal kronis, penyakit jantung ataupun stroke. Mencapai target gula darah yang terkendali baik merupakan hal yang sangat sulit bagi pasien akibat perilaku kurang disiplin dalam melakukan pengobatan maupun melaksanakan diit makanan yang merupakan standar pengobatan DM. Dukungan keluarga dekat sangat dibutuhkan dalam menegakkan disiplin pasien DM untuk mematuhi pengobatan dan pola makan yang sesuai instruksi dokter. Kegiatan PKM ini bertujuan untuk membentuk kelompok pengawas minum obat dan pola makan pada mitra yang akan memantau pasien DM dalam mematuhi instruksi dokter.

Kegiatan PKM dimulai dengan sosialisasi kegiatan, focus group discussion, pelaksanaan kegiatan serta evaluasi hasil kegiatan. Adapun outcome dari PKM ini adalah terdapat peningkatan pengetahuan mitra mengenai penyakit DM, baik dari penyebab, gejala penyakit, pengobatan serta pola diit penderita DM. Dari hasil kegiatan PKM didapatkan bahwa terjadi peningkatan pengetahuan mitra mengenai penaykit DM, pengobatan serta pola diit DM sebesar 80\%. Outcome kegiatan berupa regulasi kadar gula darah terkontrol baik dengan melakukan pemeriksaan kadar gula darah puasa dan 2 jam PP menunjukkan perbaikan sebesar $80 \%$.

Kata kunci: penguatan peran keluarga, DM, kontrol gula darah

\section{Pendahuluan}

Diabetes Melitus (DM) merupakan kelompok penyakit metabolik yang ditandai dengan tingginya kadar glukosa di dalam darah (hiperglikemia) yang diakibatkan gangguan

sekresi insulin, penurunan kerja insulin atau akibat dari keduanya. ${ }^{1} \mathrm{DM}$ terdiri dari empat tipe yaitu DM tipe 1, DM tipe 2, DM Sekunder, dan DM gestasional. ${ }^{2}$ DM ditandai dengan tingginya kadar glukosa dalam darah yaitu
\end{abstract}


kadar glukosa darah puasa lebih dari 126 mg/dl atau glukosa darah dua jam setelah makan lebih dari $200 \mathrm{mg} / \mathrm{dl}$, dimana gejala khas yang timbul dari DM adalah poliuri, polidipsi dan polifagi. Selain itu gejala DM dapat berupa kelemahan umum, gata-gatal, kesemutan dan penglihatan kabur.

Diabetes mellitus adalah penyakit kronis progresif yang merupakan masalah global. ${ }^{3}$ Prevalensi penyakit ini semakin bertambah, tidak hanya dilakangan penduduk di daerah perkotaan tetapi juga di daerah pedesaan. hal ini diperkirakan akibat gaya hidup yang semakin berubah dengan majunya sarana informasi dan teknologi di masyarakat. ${ }^{4}$ Jumlah penderita DM di Indonesia diperkirakan mengalami peningkatan mencapai 21,3 juta orang pada tahun 2030, sedangkan hasil Riset Kesehatan Dasar (Riskesdas) tahun 2007, diperoleh bahwa proporsi penyebab kematian akibat DM pada kelompok usia 45-54 tahun di daerah perkotaan menduduki peringkat ke-dua yaitu $14,7 \%$ dan daerah pedesaan, DM menduduki peringkat keenam yaitu $5,8 \% .^{5}$

Gaya hidup yang tidak sehat seperti kurang berolah raga, stress, kesibukan kantor, pola makan tidak sehat serta pengaruh genetik/ keturunan juga memberikan kontribusi yang tinggi terhadap kejadian diabetes. Komplikasi penyakit diabetes muncul setelah beberapa tahun menderita diabetes. Komplikasi diabetes dapat menyerang pembuluh darah otak, mata, jantung, ginjal dan pembuluh darah tepi. ${ }^{3}$

Kasus diabetes di Kabupaten Gianyar masih tinggi mengingat kabupaten ini merupakan daerah wisata terkenal di dunia dimana penduduknya banyak yang membuka usaha berjualan babi guling dan penduduknya juga banyak yang sering mengonsumsi babi guling. Jumlah pengunjung puskesmas dan poliklinis penyakit dalam RS Sanjiwani Gianyar paling banyak dikunjungi oleh pasien diabetes yang melakukan kontrol setiap bulan. ${ }^{6,7}$ Rerata $68 \%$ dari kunjungan pasien tersebut masih menunjukkan bahwa kontrol gula darah penderita diabetes mellitus tersebut masih di atas target kontrol gula darah yaitu $<200 \mathrm{mg} \%$. Hal ini disebabkan pasien tersebut tidak patuh dalam mengonsumsi obat-obatan yang seharusnya rutin dikonsumsi. Begitu pula pasien jarang melakukan olah raga rutin yang dapat membantu penurunan kadar gula darah. Keharusan melakukan diet rendah gula juga sering dilanggar sehingga seringkali kadar gula darah bahkan mencapai $300 \mathrm{mg} \%$ pada saat melakukan pemeriksaan kontrol. Alasan dari hal tersebut di atas adalah akibat tidak adanya pengawas minum obat pada pasien diabetes tersebut dan usia pasien rata-rata berusia lanjut sehingga terkadang lupa minum obat. Pengantar pasien tersebut pada umumnya adalah ibu rumah tangga yang memiliki pekerja wiraswasta membuka toko kelontong serta usaha berjualan kue dan paling banyak jualan babi guling. Pengantar pasien tersebut memiliki masalah tidak pernah mendapatkan pengetahuan membuat pembukuan neraca keuangan untuk usaha yang mereka miliki. Hal ini mengakibatkan pengantar tersebut mengalami kerugian pada usaha jualan tersebut.

Penyakit diabetes di wilayah Gianyar seringkali dilaporkan tidak terkontrol akibat 
ketidakpatuhan pasien untuk secara teratur meminum obat anti diabetes yang disarankan dokter. ${ }^{7}$ Dukungan keluarga merupakan faktor penting dalam kontrol gula darah pasien diabetes untuk mencegah munculnya komplikasi buruk yang tidak diinginkan. ${ }^{7}$ Penatalaksanaan diabetes mellitus meliputi pengetahuan, perbaikan gizi, olahraga dan obat antidiabetes. Dukungan dari keluarga terutama dalam mengawasi diet, mengawasi minum obat sangat diperlukan untuk menjamin kadar gula darah terkontrol baik sehingga kerusakan dinding pembuluh darah yang menjadi dasar terjadinya komplikasi pada diabetes mellitus. Karena itu bantuan keluarga sebagai pengawas minum obat serta diit DM bagi keluarga dengan diabetes sangat diperlukan.

\section{Masalah, solusi pemecahan masalah mitra dan pelaksanaan PKM}

Dari observasi dan wawancara yang dilakukan pada pasien DM di RS Sanjiwani, di poliklinis RS Sanjiwani Gianyar, sebagian besar pasien mengeluhkan tidak adanya peranan keluarga dalam membantu kontrol gula darah pasien di rumah. Lebih lanjut, wawancara dengan pengantar pasien yang rata-rata adalah keluarga dekat pasien DM didapatkan permasalahan seperti tidak memahami dengan jelas penyakit diabetes mellitus, cara pengontrolan kadar gula darah pasien diabetes, banyak terjangkit penyakit yang saat ini sedang pandemi yaitu COVID-19, pendapatan yang tidak menurun akibat pandemi, dan tidak memahami manajemen keuangan keluarga dari usaha keluarga yang menjadi andalan pendapatan keluarga.
Berdasarkan data permasalahan pada mitra tersebut diatas, program PKM akan memberikan solusi berupa, pemberdayaan masyarakat dengan membentuk Kader Siaga Regulasi Gula Darah Diabetes pada kelompok penunggu pasien diabetes di RS Sanjiwani, dengan memberikan penyuluhan dan pelatihan serta pendampingan mengenai penyakit diabetes, mengawasi pasien diabetes untuk selalu minum obat secara rutin serta mengatur pola makan/diit diabetes, aktifitas fisik pasien serta memberikan pelatihan manajemen keuangan keluarga serta membuat neraca pembukuan keuangan.

Kegiatan PKM diawali dengan sosialisasi kegiatan, focus group discussion untuk identifikasi masalah mitra dan solusi pemecahan, pelaksanaan kegiatan PKM serta evaluasi kegiatan. Kegiatan PKM diawali dengan pre-test untuk mengetahui pengetahuan mitra mengenai penyakit dan kontrol terhadap diabetes, kemudian diikuti dengan penyuluhan menggunakan pamphlet, poster, pemutaran video edukasi serta peragaan pola makanan untuk diit penderita diabetes, kegiatan fisik yang dilakukan pada pasien diabetes. Materi penyuluhan berupa pemahaman penyakit diabetes, dari penyebab, faktor risiko, gejala dan tanda, tata laksana, serta kontrol terhadap jumlah dan jenis makanan yang bisa dikonsumsi oleh pasien diabetes serta kegiatan fisik yang harus dilakasanakan oleh pasien setiap hari. Tanya jawab interaktif dilakukan pada akhir sesi penyuluhan. Materi lain selain penyakit diabetes, sesuai masalah pada mitra juga dilaksanakan pelatihan mengenai 
manajemen keuangan, pembuatan neraca pembukuan usaha keluarga yang dimiliki oleh mitra. Kondisi situasi pada saat situasi pandemi COVID-19 dimana semua anggota mitra terdampak pandemi secara ekononmi masih terjadi, mitra diberikan bantuan berupa alat pelindung diri berupa masker dan hand sanitizer serta souvenir. Pada akhir sesi dilaksanakan post-test untuk mengukur penyerapan materi yang diberikan. Evaluasi terhadap outcome dan output juga dilaksanakan untuk menilai keberhasilan program.

\section{Hasil kegiatan}

Adapun tahapan kegiatan PKM ini dibagi dalam beberapa tahap yait

a. Tahap Berkoordinasi dengan Mitra Tahap koordinasi dengan mitra diawali dengan cara menghubungi anggota kelompok penunggu pasien TBC untuk meminta persetujuan waktu pelaksanaan kegiatan. Dilaksanakan rapat singkat dengan anggota mitra untuk menentukan waktu pelaksanaan kegiatan yang akan dimulai dengan focus group discussion.

b. Tahap pelaksanaan kegiatan

Setelah mendapat izin, lalu tahap koordinasi dilanjutkan dengan pelaksanaan kegiatan PKM pada tanggal 28 Juni 2021. Kegiatan diawali dengan pelaksanaan pretest untuk mengukur pengetahuan peserta mengenai penyakit
DM dari penyebab, gejala, pengobatan serta evaluasi serta pentingnya kontrol pasien pada saat meminum obat yang harus dikonsumsi sepanjang hidup, yang sering menjadi pemicu kebosanan penderita yang akan memicu putus berobat serta munculnya komplikasi DM baik komplikasi akut maupun kronis. Setelah itu pemberian materi penyuluhan mengenai penyakit mengenai penyakit DM dari penyebab, gejala, pengobatan serta evaluasi serta pentingnya kontrol pasien pada saat meminum obat yang harus dikonsumsi selama hidup. Mitra diharapkan berperan penting dalam mengawasi penderita dalam meminum obat-obatan secara rutin untuk dapat mengontrol penyakit, serta pengawasan diit penderita DM.

Tanya jawab dilaksanakan setelah pemaparan materi. Banyak pertanyaan yang diajukan oleh peserta mengingat ini merupakan penyuluhan pertama kali mengenai penyakit DM terutama masalah pengobatan DM dan diit DM. Pada akhir kegiatan post test dilaksanakan untuk mengukur hasil kegiatan. Jumlah mitra adalah 5 orang penunggu pasien DM yang ada di ruang rawat inap maupun ruangan poliklinis RS Sanjiwani Gianyar. 

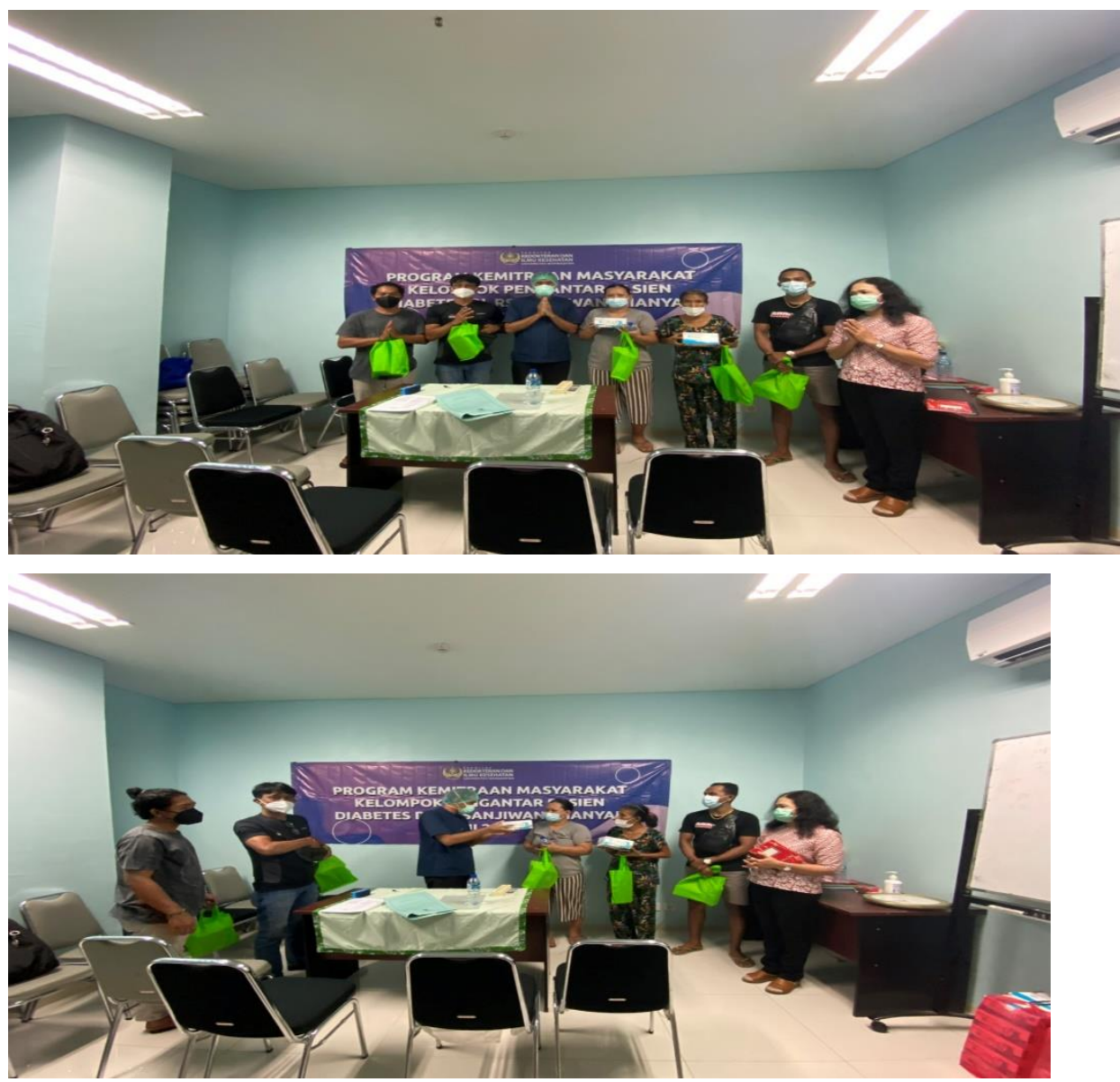

Gambar 1. Koordinasi dan Pelaksanaan kegiatan PKM

Hasil kegiatan telah meningkatkan pengetahuan mitra sebesar $80 \%$ yang diukur dari peningkatan pengetahuan mengenai penyakit diabetes, diit dan pola makan pada diabetes serta kegiatan fisik yang harus dilakukan oleh penderita diabetes. Hasil jangka panjang akan diukur dari terkontrolnya kadar gula darah pasien, berkurangnya kebutuhan obat serta terhambatnya komplikasi jangka panjang DM. Hal ini akan diukur setiap triwulan pada kedatangan pasien ke poliklinis RS Sanjiwani.

\section{Kesimpulan dan saran}

Kesimpulan dari kegiatan PKM adalah bahwa pemberdayaan masyarakat untuk membantu program pemerintah khususnya dalam penyakit DM sangat diperlukan karena dapat menurunkan risiko risiko munculnya komplikasi yang tidak diinginkan akibat pengobatan DM seumur hidup dan harus mengonsumsi obat dalam jumlah banyak untuk mencegah munculnya komplikasi DM.

Saran untuk masyarakat bahwa kegiatan semacam ini harus diteruskan karena sangat bermanfaat untuk penderita DM, keluarga, masyarakat dan tentunya pemerintah yang akan sangat terbantu dalam kontrol penyakit DM serta mencegah pasien mengalami komplikasi 
yang akan menambah beban pengobatan serta penurunan kualitas hidup pasien.

\section{Ucapan terimakasih}

Terimakasih kepada Fakultas Kedokteran dan Ilmu Kesehatan Universitas Warmadewa yang telah mendanai kegiatan PKM. terimakasih kepada tim PKM, dan mitra yang telah bekerja sama untuk kesuksesan kegiatan PKM ini.

\section{Daftar pustaka}

1. Seaquist ER, Anderson J, Childs B, Cryer P, Dagogo-Jack S, Fish L, et al. Hypoglycemia and diabetes: a report of a workgroup of the American Diabetes Association and the Endocrine Society. J Clin Endocrinol Metab. 2013;98(5):184559.

2. Eliana F, SpPD K, Yarsi B. Penatalaksanaan DM Sesuai Konsensus Perkeni 2015. PB Perkeni Jakarta. 2015;

3. Putra AAGM, Saraswati MR. PREVALENSI DIABETES MELITUS TIPE 2 DENGAN HIPERTENSI DI RSUP SANGLAH DENPASAR TAHUN 2015. E-Jurnal Med Udayana. 9(8):97-
100.

4. Paramita DP, Lestari AAW. Pengaruh Riwayat Keluarga Terhadap Kadar Glukosa Darah Pada Dewasa Muda Keturunan Pertama Dari Penderita Diabetes Mellitus Tipe 2 di Denpasar Selatan. E-Jurnal Med Udayana. 2019;8(1).

5. Idris H, Hasyim H, Utama F. Analysis of diabetes mellitus determinants in Indonesia: a study from the Indonesian Basic Health Research 2013. Acta Med Indones. 2017;49(4):291-8.

6. Trisnawati S, Widarsa T, Suastika K. Faktor risiko diabetes mellitus tipe 2 pasien rawat jalan di Puskesmas Wilayah Kecamatan Denpasar Selatan. 2013;

7. Suardana IK, Rasdini A, Kusmarjathi NK. Hubungan Dukungan Sosial Keluarga Dengan Kualitas Hidup Pasien Diabetes Melitus Tipe II Di Puskesmas IV Denpasar Selatan. J Skala Husada. 2015;12(1):96-102. 